\title{
New coumarin and dihydrocinnamic acid derivatives from two Malaysian populations of Micromelum minutum
}

\begin{abstract}
Three novel compounds, two compounds and a dihydrocinnamic acid, have been isolated from two collections of Micromelum minutum and identified by means of NMR spectroscopy. A sample collected from Pahang gave the typical coumarin micromelin and a new dihydrocinnamic acid derivative of micromelin which was identified as 1,2-secodihydromicromelin. The second sample, collected from Kelantan, gave two new tetracyclic coumarins, microminutinin and 6-methoxymicrominutinin, which possess a fused bifurano system that appears to be derived by cyclization of a 7-oxygenated-8-(1,2dimethyl)propylcoumarin precursor. The structure of microminutinin is revised from that proposed in a previous paper.
\end{abstract}

Keyword: Micromelum minutum; Rutaceae; Coumarins; Microminutinin; 6methoxymicrominutinin; Dihydrocinnamic acid; 1,2-seco-dihydromicromelin; NMR spectroscopy 